\title{
$\mathrm{Mg}$ 吹き込みによる溶銑の脱硫速度*
}

\author{
中 西 恭二**. 江 島 涁 夫***

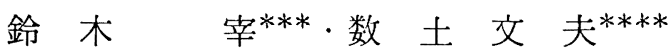

\section{On the Desulfurization Rate of Hot Metal by Magnesium Injection}

Kyoji Nakanishi, Akio EJima, Tsukasa Suzuki, and Fumio Sudo

\begin{abstract}
Synopsis:
Cold and hot model experiments have been made to investigate the kinetics of desulfurization of hot metal by magnesium granules injected with carrier gas. The followings are the major remarks obtained :

(1) The desulfurization rate is remarkably enhanced when the bath surface is covered with inert gas.

(2) It is theoretically predicted that a magnesium particle of $2 \mathrm{~mm}$ in diam. detatches from the gas jet of $200 \mathrm{~m} / \mathrm{sec}$ in linear velocity and penetrates into molten iron.

(3) By assuming the mass transfer of $\mathrm{S}$ as a rate controlling step, a theoretical prediction is made for the rates of desulfurization. The immersion depth of a lance significantly influences the rate of desulfurization; it is preferable to release magnesium bubbles from the bottom of the bath.
\end{abstract}

(4) The validity of the present model is shown by the plant scale experiments of $60 \mathrm{t}$ in heat size.

\section{1. 緒言}

近年高炉溶銑の炉外脱硫は，低硫鋼溶製上の定石とな つてきた，従来この目的の脱硫刜として， $\mathrm{CaC}_{2}$ 采脱硫 戍が広く用いられてきたが，最近になつて， $\mathrm{Mg}$ 系脱硫 剂も注目されてきた1) 8). これは彷来の $\mathrm{CaC}_{2}$ 系脱硫剂 に比較して高価であるが, $\mathrm{S}, 1 \mathrm{~mol}$ 当りの理諭消費量 でみれば， $\mathrm{Mg}$ は $\mathrm{CaC}_{2}$ の約1/2 以下の分量ですみ，生 成スラグ量も少なくしかもいわゆるカーバイト臭の問題

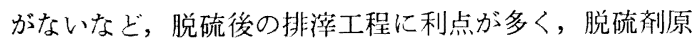
価の增分を十分吸収し得る可能性があるからである.

$\mathrm{Mg}$ 系脱硫戍による溶銑の脱硫方法には，つぎの 2 通 りがある.一つはマグ・コーク(Mg-Coke) 法と呼ばれ, コークスの空孔部に Mg を含浸させた脱硫刜を, 溶銑中 に浸漬して脱硫するものである6) -8). この場合浴の掜汼 力が比較的弱いので脱硫後も微粒の $\mathrm{MgS}$ が溶銑中に分 政し，これらの浮上分朔のためにひきつづいて $\mathrm{N}_{2}$ バブ リングが必要なこと，および処理時間が 15〜20 min と 比較的長いことなどの問題点が指摘されている33).

一方，今一つは，粒状あるいは粉状の $\mathrm{Mg}$ 系脱硫刜
をキャリヤー・ガスとともに溶銑中に吹き込むものであ る. 水野ら $14145 \mathrm{t}$ の溶銑中に種々の $\mathrm{Mg}$ 采脱硫刘を $\mathrm{N}_{2}$ ガスにより吹き込み，マグ・コーク法に匹敵する脱 硫成績を得ている. 草川ら²) は同様の実験を $5 \mathrm{~kg}$ の溶 銑で行ない，脱硫速度が二次反応に従い，見掛けの反応 速度定数が脱硫剂の添加速度に比例すると述べている. Ashton ら ${ }^{3)}$ は Mg ワイヤーとマグ・コークを比較し， $\mathrm{Mg}$ ワイヤーの方がマグ・コークよりも良好な結果を得 た・VORONOVA ら9) はランス先端部に気化室を設けるこ とにより，高炉溶銑の $\mathrm{Mg}$ 吹き込み脱硫が経済的に行な えるとしている. KURZINSKI ${ }^{5)}$ は Mg の突沸に伴う溶鋼 飛散のため，Mg の供給量には限界があり，工業規模で の $\mathrm{Mg}$ 吹き込みは経済的でないと述べている.

このように Mg 吹き込みによる溶銑の脱硫が工業的規 模で試みられるようになつてきたものの，Mg 吹き込み による脱硫反応を速度論的に研究した例2) は少ない。 こで著者らは，この問題に対して明確な知見を得るため ホットとコールドモデルを，併用した予供实験を行なっ た.これらを基礎に，実用規模に適用し得る脱硫速度の 理論式を導出し，各種操作变数の影響を議諭した。

* 昭和 51 年 10 月本会满演大会にて発表 昭和 52 年 10 月 4 日受付 (Received Oct. 4, 1977)

** 川崎製鉄 (株) 技術研究所工博 (Research Laboratories, Kawasaki Steel Corp., 1 Kawasaki-cho Cihiba 280)

*** 川崎製鉄 (株) 技術研究所 (Research Laboratories, Kawasaki Steel Corp.)

**** 川崎製鉄 (株) 千葉製鉄所 (Chiba Works, Kawasaki Steel Corp.) 


\section{2. 予 備 実 験}

\section{$2 \cdot 1$ ホット・モデル実験}

$2 \cdot 1 \cdot 1$ 実験方法

$30 \mathrm{kVA}$ 高周波溶解师を用いて実駼した，装置の概略 を Fig. 1 に示す. 加熱コイル内に内径 $145 \mathrm{~mm}$ の市贩 のマグネシャるつぼをセットして約 $15 \mathrm{~kg}$ の鉄鉄 $(4.5$ $\% \mathrm{C}, 0.5 \% \mathrm{Si}, 0.7 \% \mathrm{Mn}, 0.04 \sim 0.06 \% \mathrm{~S})$ を溶かし $1450^{\circ} \mathrm{C}$ に保持する. 浴の深さは $130 \mathrm{~mm}$ である. こ れに $8 \mathrm{~mm}^{\phi} \times 12 \mathrm{~mm}^{\phi}$ のムライト質アルミナ管を浴面 下 $70 \mathrm{~mm}$ の深さに浸清し，所定のガスにより $\mathrm{Mg}$ 系粒 状脱硫剂を吹き込えだ．吹き込みにはガラス製手動式粉 体供給装置を用いた。実験中の $\mathrm{S}$ 濃度の变化を知るた め, 内径 $8 \mathrm{~mm}$ のシリカ・チューブにより汲上サンプル を採取し分析に供した．Sの分析は燃焼法によつた。

\section{$2 \cdot 1 \cdot 2$ 結果と検討}

実験は 6 ヒート行なった. 使用した脱硫剂は, 約 $3 \times$ $1 \times 0.2 \mathrm{~mm}^{3}$ のチップ状金属 $\mathrm{Mg}$ （純度 $95 \%$ 以上）およ び表面がカーボンで被覆された 0.5 から $5 \mathrm{~mm}^{\phi}$ の粒 状 $\mathrm{Mg}$ (純度 $50 \% \mathrm{Mg}-50 \% \mathrm{C}$ ) の 2 種類である.

実験条件と脱硫成績をまとめて Table 1 に示与. Fig. 2 は代表的ヒートについて，S 浱度の経時变化を示した もので，脱硫が最もよく進行したヒートはN1である.

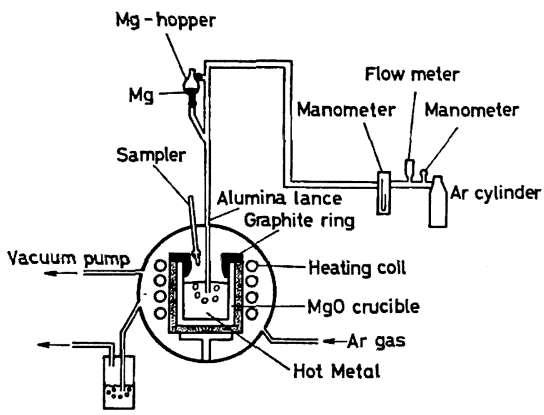

Fig. 1. Apparatus for hot model study of magnesium-injection into hot metal.

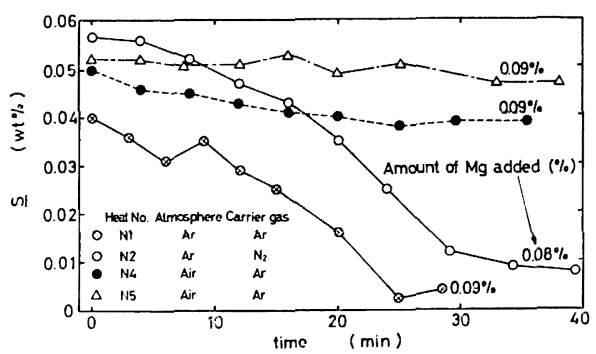

Fig. 2. Change of $\mathbf{S}$ content in the course of magnesium injection.
このヒートでは炉内雾围気を $\mathrm{Ar}$ とし， $\mathrm{Mg}$ 吹き込みに も $\mathrm{Ar}$ ガスを使用した，吹き込んだ $\mathrm{Mg}$ はチップ状金属 であり，その添加量 $14 \mathrm{~g}$ は溶銑重量の $0.093 \%$ に相当 する.これを流量が $1.5 \mathrm{Nl} / \mathrm{min}$ の $\mathrm{Ar}$ ガスにより 27 $\min$ 間で吹き込んだ. 脱硫剤供給速度, $G_{\mathrm{Mg}}(\mathrm{g} / \mathrm{min})$ とガス供給速度， $G_{\mathrm{gas}}(\mathrm{g} / \mathrm{min})$ の比を固気比と定義す れば，ヒートN1でのそれは，0.23 と比較的小さな值 である.N1の S 濃度は $0.040 \%$ から $0.003 \%$ まで 低下し，脱硫卒は 95\% と高かつた。

脱硫成績を評価する場合，つぎの二つの量が重要にな る. 一つは上述の脱硫率であり，これは脱硫前後の $\mathrm{S}$ 濃 度の変化量を初期 $\mathrm{S}$ 濃度で除した量である.今一つは, $\mathrm{Mg}$ 利用率であり，これは脱硫反応に有効汇寄与した $\mathrm{Mg}$ 量を添扣した全量で除した量として定義される。

Table 1より明らかなように，脱硫率におよぼす炉内 雲囲気の影響は大きい.すなわち Ar 雾囲気下での脱硫 率は 86〜95\% と高いが，炉内雾囲気が大気となると脱 硫率は 10～15\% と著しく低下し，かつ，ばらつきも大 となる、これは，いつたん生成した $\mathrm{MgS}$ が大気の酸素 と（1）式の反応を起こし，浴は復硫するためであろう.

$$
\begin{gathered}
\operatorname{MgS}(s)+1 / 2 \mathrm{O}_{2}(g)=\mathrm{MgO}(s)+\underline{\mathrm{S}} ; \\
\left.\Delta G_{1}^{0}=-73730+7.12 T^{10}\right) \ldots \ldots \ldots . .
\end{gathered}
$$

ここに, $\Delta G_{1}^{0}$ は反応の標準自由エネルギー $(\mathrm{cal} / \mathrm{mol})$, $T$ は絶対温度 (K) である.

$\Delta G_{1}^{0}$ は $1673 \mathrm{~K}$ で $-62 \mathrm{kcal} / \mathrm{mol}$ と俱に著しく大 きく上述の推論と矛盾しない，本実験で得られた $\mathrm{Mg}$ 利

Table 1. Experimental results of desulfurization

\begin{tabular}{|c|c|c|c|c|c|c|c|}
\hline \multicolumn{2}{|c|}{ Heat No. } & $\mathrm{N} 1$ & N2 & N3 & $\mathrm{N} 4$ & N5 & N6 \\
\hline \multicolumn{2}{|c|}{ Spec. of $\mathrm{Mg}$} & Met* & Met & Met & Met & $\mathrm{C}^{* *}$ & Met \\
\hline \multicolumn{2}{|c|}{$\begin{array}{l}\text { Carrier gas } \\
\text { (Nl/ } \mathrm{min})\end{array}$} & $1.5 \mathrm{Ar}$ & $1.5 \mathrm{~N}_{2}$ & $1.5 \mathrm{Ar}$ & $1.5 \mathrm{Ar}$ & $1.5 \mathrm{Ar}$ & $1.5 \mathrm{Ar}$ \\
\hline \multicolumn{2}{|c|}{ Atmosphere } & Ar & Ar & Air & Air & Air & Air \\
\hline \multicolumn{2}{|c|}{ Temp. $\left({ }^{\circ} \mathrm{C}\right)$} & \multicolumn{6}{|c|}{$1400 \sim 1450$} \\
\hline \multirow{2}{*}{$\mathrm{S}(\%)$} & initial $\left(\mathrm{S}_{0}\right)$ & $0.040^{\prime}$ & 0.056 & 0.043 & 0.050 & 0.052 & 0.051 \\
\hline & final $\left(S_{1}\right)$ & $0.002 \mid$ & 0.008 & 0.0370 & 0.039 & $0.047 \mid$ & 0.026 \\
\hline \multicolumn{2}{|c|}{$\left(1-S_{1} / S_{0}\right) \times 100(\%)$} & 95 & 86 & 14 & 22 & 10 & 49 \\
\hline \multicolumn{2}{|c|}{ Treating time $(\mathrm{min})$} & 25 & 35 & 49 & 35 & 34 & 40 \\
\hline \multicolumn{2}{|c|}{ Solid to gas ratio } & 0.23 & 0.21 & 0.09 & 0.15 & 0.37 & 0.12 \\
\hline \multicolumn{2}{|c|}{ Mg-efficiency $(\%)^{* * *}$} & 30.6 & 45.0 & 7.2 & 10.3 & 8.0 & 28.0 \\
\hline
\end{tabular}
of hot metal by magnesium injection. 
用率は，Table 1にみるように，おしなべて低い。すな わち大気下では 7〜28\%，また Ar 雲冊気下では 31〜 46\% であつた．これより吹き込んだ Mgのうち約 40\% が S と反応し，残り 60\% が気相中へ逃散したことに なる.

実験中の浴面状況は, 雲囲気によつて異なり以下のよ うであつた. 大気下の実験では，浴面上で激しい発光を 伴つて Mg 蒸気が酸化する. 一方 $\mathrm{Ar}$ 等囲気下では発光 は全くなく，Mg 蒸気が黒煙として吹き上げる. $\mathrm{Mg}$ の キャリャーガスとして $\mathrm{N}_{2}$ を使用すると, 浴面は $\mathrm{Mg}_{3} \mathrm{~N}_{2}$ とみられる薄膜状スラグでおおわれる. $\mathrm{Mg}_{3} \mathrm{~N}_{2}$ の生成 は以下の熱力学的数值からも妥当な推論と考えられる.

$$
\begin{gathered}
3 \mathrm{Mg}(e)+\mathrm{N}_{2}(g)=\mathrm{Mg}_{3} \mathrm{~N}_{2}(s) ; \\
\left.\Delta G_{2}^{0}=-115750+54.09 T^{10}\right) \\
3 \mathrm{Mg}(g)+\mathrm{N}_{2}(g)=\mathrm{Mg}_{3} \mathrm{~N}_{2}(s) ; \\
\left.J G_{3}^{0}=-207500+121.25 T^{10}\right)
\end{gathered}
$$

(2) 式は1061〜1300K について，また（3）式は， $1500 \sim 2000 \mathrm{~K}$ の温度範囲について，それぞれ 成り立 つ. これらの反応式より, $1440^{\circ} \mathrm{C}$ 以下の温度で $\mathrm{Mg}_{3} \mathrm{~N}_{2}$ が生成し得ることが明らかである. Table 1 に示す以外 の実験ヒートで，キャリャー・ガスに $\mathrm{N}_{2}$ を使用してラ ンス詰まりを生じたものがある．この時のランス内閉塞 物をX線回折により同定したところ，Fig. 3 に示すよう に， $\mathrm{Mg}_{3} \mathrm{~N}_{2}, \mathrm{MgO}, \mathrm{Mg}$ などが検出された。この閉塞 物を大気中に放置すると，アンモニヤ臭を発生すること から $\mathrm{Mg}_{3} \mathrm{~N}_{2}$ は湿分と反応して容易に $\mathrm{MgO}$ になるよう である. 以上の事柄から，先の薄膜状スラグが $\mathrm{Mg}_{3} \mathrm{~N}_{2}$ であることは確かであろう.しかしキャリヤーガスに， Ar と $\mathrm{N}_{2}$ を用いた場合の脱硫速度がほぼ等しく（Fig. 2), 浴面からの黑煙発生の程度にも差異は認められな かつたことから，脱硫速度を考える場合に $\mathrm{Mg}_{3} \mathrm{~N}_{2}$ の影 響は無視し得るであろう。

結局，本子備実験を通して粒状 $\mathrm{Mg}$ 吹き込みによる脱

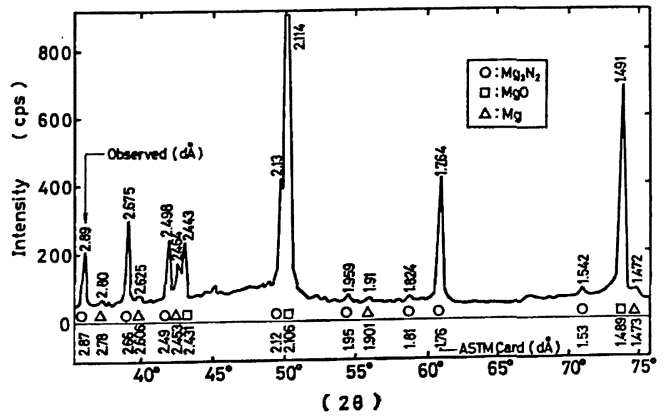

Fig. 3. X-ray diffraction pattern of the material clogged in the lance.
硫反忘の様相は以下のごとく要約されよう，吹き込まれ た粒はガスバブルとして浮上し，途中その一部が溶銧中 の $\mathrm{S}$ と絬びつき,一部は未反応のまま気相へ放出される。 浴面に分崩した悦硫生成物， MgS は，気相中の酸素分 正が例えば大気のそれのように高いと，容易に酸化され $\mathrm{S}$ は再び浴中へ戻される，この場合脱硫と復硫反応が競 合して進むので脱硫速度は著しく低下与ると同時に反応 機槛自体複䧱となる.

上記の反応モデルにより現場での脱硫速度を理論的に 組立てることができるが，その際重要となるのは吹き込 んだ Mg 粒が，キャリヤーガスから離脱し得るか否かで ある.この問題を明らかにするため，コールド・モデル 実験を行なつた。

\section{$2 \cdot 2$ コールド・モデル実験}

\section{$2 \cdot 2 \cdot 1$ 実験方法}

実験に使用したガラス憋ランスの形状はL 型で，固気 流の噴出口となる水平部の寸法は内径 $5.8 \mathrm{~mm}$ ，長さ 31 $\mathrm{mm}$ である.これを水を張つた塩ビ製水盙（100 mm幅 $\times 470 \mathrm{~mm}$ 長 $\times 600$ 高）に，吹き込み口が水槽の長辺方向 と平行になるよう垂直に浸漬した。所定流量の $\mathrm{N}_{2}$ ガス により水中に吹き込んだ固体粒子は, 発泡アルミナ粒, スチロール粒などであり，それらは Table 2 に示すサ イズと比重を有する．吹き込みに際しては前節で使用し たと同じガラス製の手動ホッパーを用い水榑の長辺面か らガス・ジェットと吹き込み粒子の軌跡を写真撮影によ り観測した。

\section{$2 \cdot 2 \cdot 2$ 結果と考察}

$\mathrm{N}_{2}$ ガス流量を $10 \mathrm{Nl} / \min$ として撮影した結果の 2 例 を Photo. 1 に示す. Photo. 1 (a) は 2 2.8 $\%$ の中空 アルミナ粒を吹き込んだ場合の粒子とガス・ジェットの 軌跡を示している．これより明らかなように，アルミナ 粒子はガス・ジェットの前方の液中に押出されている.

このアルミナ粒の比重は，表面の殼が破れていなけれ ば，Table 2 に示すように 0.51 と水より軽いが，破研

\begin{tabular}{|c|c|c|c|}
\hline Material & Diam. & Density & Apparent density*** \\
\hline Alumina & $\begin{array}{l}1 \mathrm{~mm} \\
1-1.4 \\
2-2.8\end{array}$ & $\begin{array}{l}1.95^{*} \\
3.09^{*} \\
0.51 * *\end{array}$ & $\begin{array}{l}0.83 \\
0.91 \\
0.56\end{array}$ \\
\hline Styrene & 3.5 & 0.02 & \\
\hline
\end{tabular}
すればアルミナの比重，4に近づき水中で落下する.ガ

Table 2. Density and diam. of the particles used for the cold model experiment.

* the weight of $3 \mathrm{cc}$ was measured both in water and in air

** the particles with sound surface were selected and measured.

*** the weight of $100 \mathrm{cc}$ was measured in air. 


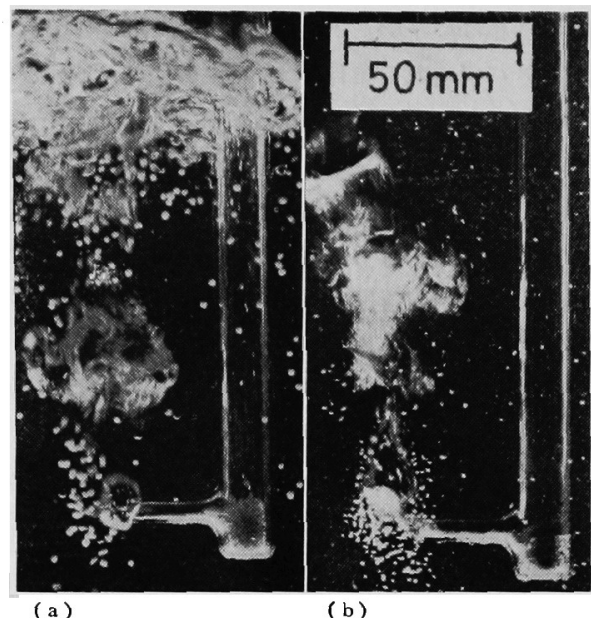

(a) $101 \mathrm{~N}_{2} / \mathrm{min} 2-2.8 \mathrm{~mm}$ in diam. (b) $101 \mathrm{~N}_{2} / \mathrm{min} 1-1.4 \mathrm{~mm}$ in diam.

Photo. 1. Behavior of pored alumina particles injected into water with nitrogen gas.

ス・ジェットからの粒子の離脱は, 比重が 0.51 と柽い ものについても, $10 \mathrm{Nl} / \mathrm{min}$ 以上のガス流量で起こつて いる.

Photo. 1（b)は 1〜1.4 mm $\phi$ のルミナ档を吹き込 んだ場合を示している. 先と同様にアルミナ粒子はガス ジェットをつき破つて前方の液中へ押出されている。一 方，径が $3.5 \mathrm{~mm}$ の発泡スチロール粒を吹き込えだ場合 は，粒子は軽すぎて，ガス気泡にくるまれたまま浮上し $\neq$.

このような写真を吹き込み条件別に，てれぞれ 5〜15 枚撮影し，これから Fig. 4 に示寸粒子離脱距離 $\left(x_{1}\right)$ を測定した・ $x_{1}$ はガスジェットの先端から噴出粒子群先 端までの水平距嶉である。結果を Fig. 5 に示した。た とえば 2 2.8 $\mathrm{mm}^{\phi}$ のアルミナ粒子の $x_{1}$ は，10 $1 / \mathrm{min}$

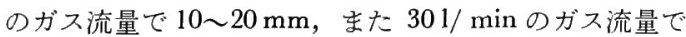
は 20〜60 $\mathrm{mm}$ とガス流量とともに増加する.

さて，ここでガスとともに吹き込んだ固体が，ガス． ジェットから離脱する条件を理論的に検討してみよう. すでに ENGH ら 11) は固体の有する運動エネルギーが界 面エネルギーの変化に打勝つて，なお残余の運動エネル ギーを有するための条件として理論式を導いた，そこで 本実験の一例を想定して，10 1/min のガス流量で比重 が 0.51 のアルミナ粒子を吹き込む場合について試算す れ代，径が $0.06 \mathrm{~mm}$ を越える粒子はすべてガス・ジェ ットをつき破り，液中へ飛び出すことになるこのこと

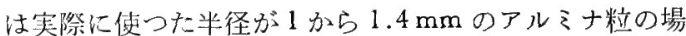
合，界面エネルギーの変化による粒子の減凁効果は著し く小さく，舆視できることを示している.したがって，

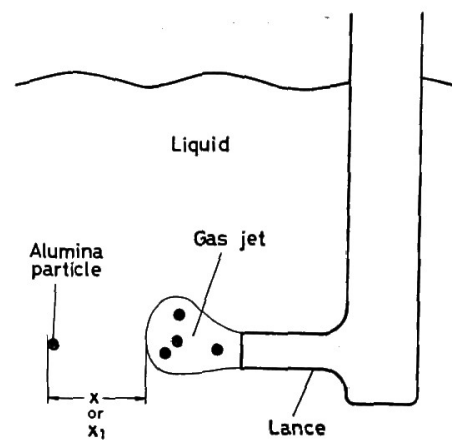

Fig. 4. Distance of detachment of alumina particles from the leading edge of gas jet.

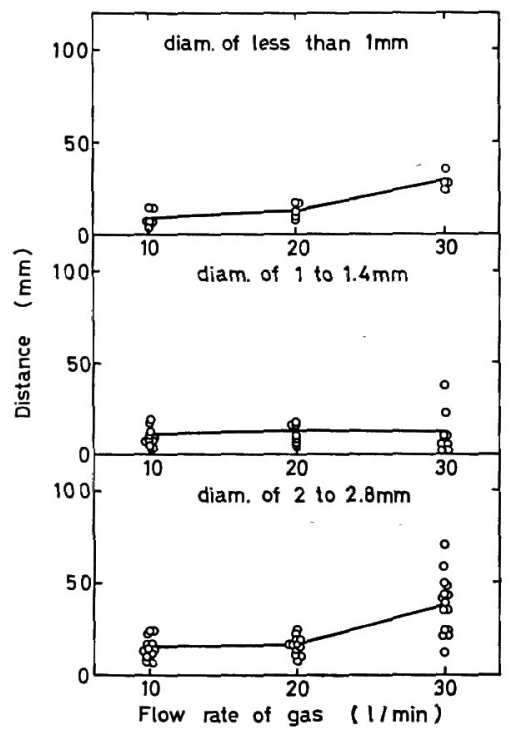

Fig. 5. Distance of detachment of alumina particles measured from the leading edge of gas jet.

先化実験で求めた粒子離脱距離， $x_{1}$ は運動エネルギー の摩擦損失のみを考えれば理論的にも推定し得ることに なる。

半径 $r$, 密度 $\rho_{p}$ の固体粒子が, 初速度 $v_{0}$ でガス・ ジェットの先端から, Fig. 4 に示す距離 $x$ だけ液中へ飛

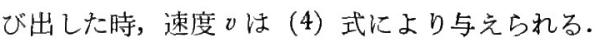

$$
\begin{aligned}
& -\frac{4 \pi r^{3}}{3} \frac{\rho_{p}}{2} v_{0}^{2}-\frac{\pi r^{2} \rho_{p} k_{f}}{2} \int_{0}^{x} v^{2} d x \\
& =\frac{4 \pi r^{3}}{3}-\frac{\rho_{p}}{2} \eta^{2} \ldots \ldots \ldots \ldots \ldots \ldots \ldots \ldots \ldots \ldots \ldots \ldots
\end{aligned}
$$

ここに， $\rho_{e}$ は液体の密度， $k_{f}$ は摩擦係数である。

$k_{f}$ は液体中での粒子のレイノルズ数, $N_{R e}$ に忘じて 以下の值をとることが知られている12). 
$k_{f}=0.44 ; N_{R e}=2 r v \rho_{p} / \mu_{c} \geqq 10^{3}$

$k_{f}=18.51\left(2 r v \rho_{p} / \mu_{c}\right)^{3 / 5} ; N_{R c}<10^{3}$

ここに, $\mu_{c}$ は液の粘度である。

(6) 式では $k_{f}>0.44$ が成り立つので, $k_{f}=0.44$ とお

けば，(4) 式より粒子離脱距㜠の最大值が求まる*.

（4）式を積分すれば（7）式を得る.

$$
v=v_{0} \exp \left[-\frac{3 \rho_{f} k_{f}}{8 \rho_{p} r} x\right]
$$

$N_{R e}$ が 1 となる $v ， 0.8 \mathrm{~mm} / \mathrm{sec} て ゙$ 粒子は事実上静止す るので, この条件のもとで (7) 式より粒子最大嶉脱距 離を算出すれば，径が $2.8 \mathrm{~mm}$ で比重が 0.51 のアルミ ナ粒を $101 / \mathrm{min}$ のガスで吹き込むとして $x=33 \mathrm{~mm}$ を得る.一方，これに相当する実測値は Fig. 5 にみる ように 8- $25 \mathrm{~mm}$ の間にあり，両者の値は互に近い.今 一つの例として, 発泡スチロール $\left(2 r=3.5 \mathrm{~mm}, \rho_{p}=\right.$ $\left.0.02 \mathrm{~g} / \mathrm{cm}^{3}\right)$ の場合は, $101 / \mathrm{min}$ のガス流量において $x=0.9 \mathrm{~mm}$ と粒子径よりも小さな值が得られ，ガス・ジ ェットからの離脱が不可能なることを示す.これらは実 験結果とよく一致する.（7）式に $N_{R e}=1$ なる条件を代 入し, 粒子離脱距離, $x$ について解けば $(8)$ 式を得る.

$$
x=\left(61.4 \rho_{p} r / \rho_{e} k_{f}\right) \log \left(2 v_{0} \rho_{p} r / \mu_{e}\right)
$$

元来, このような理論式は, 絶対的な信頼性にはそしい ので, 式の構造を理論式から決め, その補正係数は実験 的に求めるべきであるが，上述のごとく，理論式は実測 值をオーダー的によく説明しているので，ここでは粒子 離脱距離の目安を得る目的で, (7), (8) 式を近似的に 用いることにする。

たとえば，後述する現場設定条件の一例として，内径 が $25.4 \mathrm{~mm}$ の逆Y型 2 孔ランスを溶銑中に浸漬して, $2 \mathrm{~mm}^{\phi}$ の $\mathrm{Mg}$ 粒を $3 \mathrm{Nm}^{3} / \min$ の $\mathrm{N}_{2}$ ガスとともに吹 き込んだ場合，(8) 式より $x$ は $18 \mathrm{~mm}$ と求まる.ただ ᄂ $\rho_{e}=6.9 \mathrm{~g} \mathrm{~cm}^{-3}, \quad \rho_{p}=1.74 \mathrm{~g} \mathrm{~cm}^{-3}, \quad v_{0}=195 \mathrm{~m} / \mathrm{sec}$ および $\mu_{e}=0.05$ poise などの数值を用いた。 これより 明らかなように，現場の吹き込み条件のもとでも，適当 な粒径であれば, $\mathrm{Mg}$ 粒はガス・ジェットから離脱して 溶銑中に侵入すると結諭つけられる.

さてこのようにして吹き込まれた $\mathrm{Mg}$ 粒は，周囲の溶 銑から熱を受け，短時間で $\mathrm{Mg}$ 蒸気をなるはずであるが このためにどの程度の時間を要するかを明らかにしなけ れば，Mgによる脱硫反応モデルを組立てることができ ない.そこで次章では $\mathrm{Mg}$ 粒の蒸発速度を解析する.

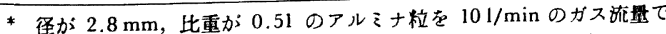
吹込んだ祭, アルミナ粒の初速度， 乙の時 $N_{R e}$ は $10^{4}$ のオーダと評価され（5）式を満足する. ジェ 卜前面からの離㙂距離の大部分は $v$ が大な時の変位であるととを 考虎すれば， $k_{f}=0.44$ の近似は許されよう。

\section{3. $\mathrm{Mg}$ 粒の気化速度}

\subsection{Mg の熱的性質}

前述のように，かりに徍 $2 \mathrm{~mm}$ の $\mathrm{Mg}$ 粒を吹き込ん だ場合を想定して計算する。この $\mathrm{Mg}$ 粒が浴面から 700 $\mathrm{mm}$ 深さの溶銑中に吹き込まれ，完全に父化すればそ の体積は $26.3 \mathrm{~cm}^{3}$, 半径が $18.4 \mathrm{~mm}$ の気泡となる.

$\mathrm{Mg}$ の相変態（融点 $923 \mathrm{~K}$, 洲点 $1390 \mathrm{~K}$ ) に伴うエ ンタルピー変化は以下のようである ${ }^{10)}$. 標準状態の固体 を $1000 \mathrm{~K}$ の液体とするのに $7.01 \mathrm{kcal} / \mathrm{mol}$ ，また同 様に $1400 \mathrm{~K}$ の気体とするのに $40.7 \mathrm{kcal} / \mathrm{mol}$ を要す る.このように, 蒸発の潜熱に比較して室温から融点亡 での昇温に要する熱は小さいので，溶銑中の $\mathrm{Mg}$ 粒は 粒中心までが沸点温度に達してから蒸発を開始すると考 えて大過なかろう. すなわち， Mg 粒は溶銑と直接接䖵 した状態で，粒中心まで沸点温度に達し，それから沸と う伝熱機構により気化するものと考える。このモデルに 従つて以下計算を進めるが，その際必要となる $\mathrm{Mg}$ の熱 的性質を Table 3 にまとめた。

\section{2 沸とう伝熱による気化速度}

溶銑との直接接触のもとで $\mathrm{Mg}$ 粒の中心までが沸点温 度 $1117^{\circ} \mathrm{C}$ になるまでの所要時間， $\tau_{1}$ は CARSLAWら ${ }^{14)}$ に従つて以下のごとく求まる。通常, 現場における脱硫 処理時の溶銑温度は $1300^{\circ} \mathrm{C}$ 程度であるので, $\mathrm{Mg}$ 粒の 外面を $1300^{\circ} \mathrm{C}$ の熱源に接触したものと仮定する.この 時, $\mathrm{Mg}$ 粒の中心温度が表面温度の 0.86 倍となる時間 を求めれば，それが求める $\tau_{1}$ である.

$$
\tau_{1}=0.3 r^{2} C_{p}^{\prime} \rho_{L} / k
$$

ここに, $\quad r$ は粒半径, $C_{p}^{\prime}$ は融解の潜熱も含めた定压比 熱, $\rho_{L}$ と $k$ は $\mathrm{Mg}$ 液体の密度と熱伝導率である.

Table 3 の諸数值より， $\tau_{1}=0.01 \mathrm{sec}$ となる．また中 心が融解するまでの時間， $\tau_{2}$ も同様にして計算される が，それは $0.005 \mathrm{sec}$ と与えられる.これらの值は $\mathrm{Mg}$ 粒の熱伝導度を液体のそれで近似し， $\mathrm{Mg}$ 粒内には強制 対流がないものとして得られたので，実際はこれらより 短いであろう.

さて，これに引続いて $\mathrm{Mg}$ 粒は $\mathrm{Mg}$ 気泡の底で溶銑と 接しながら沸とう伝熱機構により, 高速度での気化を開 始する. この時の熱伝達係数, $h$ は次式で与えられる ${ }^{15)}$.

$$
h=512\left[f_{s} f_{p}^{2} \frac{1}{\underline{M}^{2} \underline{P}} \frac{C_{p} k^{2} \rho_{L}^{2}}{\sigma \lambda \rho_{V}}\right] \Delta T^{2}
$$

ここに, $h$ は熱伝達係数 $\left(\mathrm{kcal} / \mathrm{m}^{2} \cdot \mathrm{h}^{\circ} \mathrm{G}\right), C_{p}$ は $\mathrm{Mg}$ 液 体の比熱 $\left(\mathrm{kcal} / \mathrm{kg}^{\circ} \mathrm{K}\right), \sigma$ は $\mathrm{Mg}$ 液体の表面張力 $(\mathrm{kg}$ $/ \mathrm{m}), \underline{M}$ は $900 \mathrm{~m}^{-1}, \underline{P}$ は $1.699 \mathrm{kcal} / h, f_{p}$ は圧力 比でここでは 1.5 をとる, $f_{s}$ は起泡度と呼ばれ, 溶銑 
Table 3. Thermo-physical properties of magnesium

\begin{tabular}{|c|c|c|c|}
\hline Properties & $\mid \begin{array}{l}\text { Desig- } \\
\text { nation }\end{array}$ & Values & References \\
\hline $\begin{array}{l}\text { Mean value of specific } \\
\text { heat including latent } \\
\text { heat of vaporization }\end{array}$ & $C_{p^{\prime}}$ & $\left|\begin{array}{c}0.408 \mathrm{kcal} / \\
\mathrm{kg}^{\circ} \mathrm{C}\end{array}\right|$ & (10) p. 543 \\
\hline $\begin{array}{l}\text { Thermal conductivity } \\
\text { of liquid }\end{array}$ & $k$ & $\begin{array}{l}72 \mathrm{cal} / \\
\mathrm{m} \cdot \mathrm{h}^{\circ} \mathrm{C}\end{array}$ & (13) p. 985 \\
\hline Density of liquid & $\rho_{L}$ & $\begin{array}{r}1740 \\
\mathrm{~kg} / \mathrm{m}^{3}\end{array}$ & (10) p. 539 \\
\hline Surface tension & $\gamma$ & $\begin{array}{l}0.058 \\
\mathrm{~kg} / \mathrm{m}\end{array}$ & (15) p. 35 \\
\hline $\begin{array}{l}\text { Lateny heat of gas } \\
\text { vaporization }\end{array}$ & $\lambda$ & $\begin{array}{l}1250 \\
\mathrm{kcal} / \mathrm{kg}\end{array}$ & (10) p. 537 \\
\hline $\begin{array}{c}\text { Density of gas at } 1.5 \\
\text { atm. and } 1300^{\circ} \mathrm{C}\end{array}$ & $\rho_{V}$ & $\begin{array}{c}0.283 \\
\mathrm{~kg} / \mathrm{m}^{3}\end{array}$ & \\
\hline Specific heat of gas* & $\overline{C p}$ & $\begin{array}{c}0.533 \mathrm{kcal} / \\
\mathrm{kg}^{\circ} \mathrm{C}\end{array}$ & (20) \\
\hline $\begin{array}{l}\text { Thermal conductivity } \\
\text { of gas }\end{array}$ & $\bar{k}$ & $\mid \begin{array}{c}0.04123 \mathrm{kcal} \\
/ \mathrm{m} \cdot \mathrm{h}^{\circ} \mathrm{G}\end{array}$ & (20) \\
\hline Viscosity of gas** & $\bar{\mu}$ & $\left|\begin{array}{c}0.114 \\
\mathrm{~kg} / \mathrm{m} \cdot \mathrm{h}\end{array}\right|$ & (20) \\
\hline Enthalpy of vapor & $\Delta H$ & $\begin{array}{l}1690 \\
\mathrm{kcal} / \mathrm{kg}\end{array}$ & (10) \\
\hline Specific heat of liquid & $C_{p}$ & $\begin{array}{r}0.33 \mathrm{kcal}^{\circ} \\
/ \mathrm{kg}^{\circ} \mathrm{C}\end{array}$ & $(10)$ \\
\hline
\end{tabular}

* assumed to be equal to that of sodium.

** predicted assuming $\bar{\mu} \infty \sqrt{M^{1} \cdot T b / d^{2}}$ where $M^{1}$ is molecular weight, $T b$ is boiling point and $d$ is atomic diam.

と $\mathrm{Mg}$ 粒との接蟲面積の中で気泡発生に有効な面積，ま た $J T$ は溶銑と $\mathrm{Mg}$ 液体の温度差である。

Table 3 の諸数值より (10) 式は (11) 式となる。

$$
h / f_{s}=8.47 \times 10^{9}\left(\mathrm{kcal} / \mathrm{m}^{2} \mathrm{~h}^{\circ} \mathrm{C}\right)
$$

$\mathrm{Mg}$ 粒が球形として, 熱伝導式は (12) 式で与えられる.

$$
-4 \pi r^{2} \frac{d r}{d t} \rho_{L} \lambda=4 \pi r^{2} \alpha h \Delta T
$$

ここに， $\alpha$ は全表面積の中で，溶銑と接伿する面積の制 合を意味する。

（12）式を積分し（11）式に代入すれば， Mg 粒の蒸 発所要時間， $\tau_{3}$ は，(13) 式で与えられる.

$$
\tau_{3}=1.03 \times 10^{-8} / \alpha \cdot f_{\mathrm{s}}[\mathrm{sec}] \cdot
$$

$f_{\mathrm{s}}$ は伝熱面がたとえばパイプのような固体面をなし， その表面の凹凹が場所によつて異なつたり，あるいは表 面の污れが気泡発生頻度に場所によるむらをつくる場合 に，1より小なる值をとるが，今回のごとく伝熱面が液 体面でしかも温度差が $180^{\circ} \mathrm{C}$ とかなり大きい時には 1 とおける。したがって（13）式より，球面の1\%しか溶 銑と接触していないとしても， $\tau_{3}$ は $10^{-6} \mathrm{sec}$ のオーダ 一であり，沸とう伝熱機棈が作用しはじめれば， Mg の 蒸発は瞬時に完了することになる. 後述するように, 半 径 $18.4 \mathrm{~mm}$ の気泡が $700 \mathrm{~mm}$ の浴深さを浮上するに 要する時間に比較して，上述の蒸発所要時間は十分短く 吹き込まれた粕は完全に気化した後気泡として浮上を開
始すると考えてよいであろうところで，Mg の吹き込 みに使用したガス・ジェットも微細な気泡群**に分散す るので，これらの気泡群と $\mathrm{Mg}$ 気泡群との間には合体の 可能性が残る。しかし，Mg 粒の気化，膨張は周囲の溶 銑を排除しつつ進行するので，周囲のキャリヤー・ガス 気泡もそれとともに排除され，合体を防止する可能性も 十分にあるので，ここでは $\mathrm{Mg}$ 気泡とキャリヤー・ガス 気泡の合体はないものとして以下の計算を進める.

\section{Mg 吹込みによる溶銑脱硫の反応速度式}

\section{$4 \cdot 1$ モテルの概要}

前章までの実験と理諭的検討の結果，現場スケールで の Mg吹き込みによる溶銑脱硫の反応機構として，つぎ のようなモデルが妥当であろう.

$\mathrm{N}_{2}$ ガスとともに吹き込まれた $\mathrm{Mg}$ 粒はガスジェット から離脱して直ちにガス気泡となる．との後 $\mathrm{Mg}$ 気泡は 浮上を開始して溶銑中の $\mathrm{S}$ の拡散が律速となつて脱硫が 進む. この際，溶銑中への $\mathrm{Mg}$ の溶解度は低いので， $\mathrm{Mg}$ が溶銑中を拡散して MgS 生成する機構は無視で きるであろう・溶銑浴面が空気などのような酸化性ガス でお抢われていると，いつたん生成した $\mathrm{MgS}$ が酸化さ れ，それに伴う復硫反応が脱硫反応と平行して進み，反 応は複䧱となるので，一応復硫はないものと仮定する。 もつとも，Mg 脱硫を経済的方法として実用化するため に, この条件が必須であることは，先の実験室で行なつ た実験結果からも自明といえる．最後に， $\mathrm{N}_{2}$ ガスとと もに吹き込まれた $\mathrm{Mg}$ 溔力学的に $\mathrm{Mg}_{3} \mathrm{~N}_{2}$ を生成する 可能性があるが，その程度は小さく脱硫反応の律速段階 に影響をおよぼすほどのものではない。

\section{2 基礎式の導出}

$2 \mathrm{~mm}^{\phi}$ の $\mathrm{Mg}$ 粒は $1300^{\circ} \mathrm{C}$ で気化することにより， 浴面下 $700 \mathrm{~mm}$ の位置で半径が $18.4 \mathrm{~mm}$ の気泡とな る. 気泡半径 $r$ と浮上速度, $v_{\infty}$ の間には，(14) 式の成 り立つことが知られている16).

$$
v_{\infty}=1.02 \sqrt{g \underline{r} .}
$$

ここに，g情力加速度 $\left(980 \mathrm{~cm} / \mathrm{sec}^{-2}\right)$ である.

(14) 式に $r=18.4 \mathrm{~mm}$ を代入すれ澕＼cjkend， $v_{\infty}=0.433 \mathrm{~m}$ $/ \mathrm{sec}$ ，と評価される.この気泡浮上所要時間は，約 1.6 sec である。

半径が $18.4 \mathrm{~mm}$ と大きな気泡は溶銑中で球形帽子状 (spherical cap) を呈することが知られている。この場 合の物質移動係数, $k_{B D}(\mathrm{~cm} / \mathrm{sec})$ は BAIRD ら ${ }^{17)}$ によ

* ランス出口でのガス・レイノルズ数が 104 オーダであるので，たと

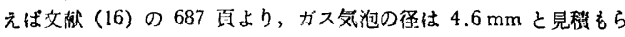
れる。 
り（15）式で与えられる.

$$
k_{B D}=0.82 D_{i}^{1 / 2} v_{\infty}^{1 / 2} r^{-1 / 2}
$$

ここに， $D_{i}$ は溶銑中の $\mathrm{S}$ の拡散係数である.

今, $\mathrm{Mg}$ 気泡 1 個に注目 し，この気泡内の $\mathrm{Mg}$ 原子数 を $n$ とおく，nの変化速度は (16) 式で与えられる.

$$
d n / d t=-4 \pi \underline{r}^{2} k_{B D} \cdot C \cdot
$$

ここに，Cは溶銑バルクの $\mathrm{S}$ 濃度 $\left(\mathrm{mol} / \mathrm{cm}^{3}\right)$ である.

さて, 溶銑浴の摜拌は十分強く, $\mathrm{S}$ 濃度は脱硫処理を 通して常に均一であると仮定すれば，溶銑中の $\mathrm{S}$ 濃度は (17) 式により変化する.

$$
W \cdot d c / d t=-\left(n_{0}-n_{H}\right) N_{0} v_{0} \pi R^{2}
$$

ここに，W は浴の体積 $\left(\mathrm{cm}^{3}\right), n_{H}$ は浴面を離れる直 前の $\mathrm{Mg}$ 気泡 1 個当りの原子数で, $H$ はガス浮上開始位 置から浴面までの高さを示す. $n_{0}$ は $\mathrm{Mg}$ 気泡 1 個当り の初期原子数, $N_{0}$ はガス浮上開始位置での $\mathrm{Mg}$ 気泡の 数密度 $\left(N / \mathrm{cm}^{3}\right), v_{0}$ はガス浮上開始位置での $\mathrm{Mg}$ 気泡 の浮上速度 $(\mathrm{cm} / \mathrm{sec})$ で (14) 式から 計算される. ま た $R$ は取鍋の内半径である.

$\mathrm{Mg}$ の吹き込み速度を $M(\mathrm{~mol} / \mathrm{sec})$ とすれば，

$$
M=\pi R^{2} v_{0} N_{0} n_{0}
$$

が成り立つので (17)式は (19)式のように書換られる.

$$
d c / d t=-\frac{M}{W} \frac{n_{0}-n_{H}}{n_{0}}
$$

$\mathrm{Mg}$ 蒸気は理想気体とみることができるので（20）式が 成り立つ.

$$
\left(4 \pi r^{3} / 3\right)\left[P_{a}+\gamma(H-h)\right]=n R T
$$

ここに， $P_{a}$ は雲囲気圧で $1 \mathrm{~atm}, \gamma$ は静鉄圧係数で, $0.0067 \mathrm{~atm} \mathrm{~cm}^{-1}$ なる定数, $h$ は気泡浮上開始位置から 上向きにとつた位置座標 $(\mathrm{cm}), T$ は溶銑温度 $\left({ }^{\circ} \mathrm{K}\right)$, および $R$ は気体定数である.

（14），(15）式を代入して（16）式を変形すれば 式を得る。

$$
d n / d h=-K \underline{r}^{5 / 4}
$$

ここに，Kは (22) 式で与えられる.

$$
K=1.82 D_{i}{ }^{1 / 2} C
$$

（20）式を（21）式に代入して積分すれば（23）式を 得る.

$$
y=(1-\xi C)^{12 / 7}
$$

ただし， $y=n_{H} / n_{0} \cdots \cdots \cdots(24) \quad \xi=S \zeta / n_{0}{ }^{7 / 12}$.

$S=\left(P_{a}+\gamma H\right)^{7 / 12}-P_{a}{ }^{7 / 12} \cdots \cdots(26) \quad \zeta=K L / \gamma C \cdots \cdots$

$L=(3 R T / 4 \pi)^{5 / 12 \ldots \ldots . . . .(28)}$ である.

結局，(19) 式に（23）式を代入すれば最終式として (29) 式を得る.

$$
d c / d t=-(M / W)\left[1-(1-\xi C)^{12 / 7}\right]
$$

(29) 式を解いて， $C$ の值が知れたら， $\mathrm{Mg}$ 利用効率
$\Omega(\%)$ は (30) 式より算出される.

$$
\Omega=100 W\left(C_{0}-C_{\tau}\right) / M \tau
$$

ここに， $\tau$ は吹き込み所要時間 $(\mathrm{sec}), C_{0}$ および $C_{\tau}$ は それぞれ時刻 0 およびてにおける溶銑 $\mathrm{S}$ 浱度 $\left(\mathrm{mol} / \mathrm{cm}^{3}\right)$ である。また $\mathrm{Mg}$ 利用効率の瞬時值， $\varphi(\%)$ は，(31)式 から求まる。

$$
\varphi=100\left[1-(1-\xi C)^{12 / 7}\right]
$$

なお便利のため，つぎのパラメータ， $\beta$ を定義する.

$$
\beta=H / H_{0}
$$

ここに, $H_{0}$ は浴の全深さであり, 以後この $\beta$ のことを ガス浸漬率と呼ぶ.

\section{$4 \cdot 3$ 計算方法と結果}

計算の手順は以下のとおりである.まず（29）式を， Runge-Kutta-Gill 法により数值的に解き，ついで(30) (31) 式より $\mathrm{Mg}$ 利用効率を算出した.

計算時の吹き込み条件は以下のごとく設定した. $60 t$ 溶銑用取鍋 $\left(R=1065 \mathrm{~mm}, H_{0}=1900 \mathrm{~mm}\right)$ に $1300^{\circ}$ C の溶銑 $(4.5 \% \mathrm{C} ， 0.5 \% \mathrm{Si}, 0.5 \% \mathrm{Mn}, 0.05 \% \mathrm{~S}$ また は $\left.C_{0}=1.078 \times 10^{-4} \mathrm{~mol} / \mathrm{cm}^{3}\right)$ が $46.7 t(W=6.77 \times$ $\left.10^{6} \mathrm{~cm}^{3}\right)$ 保持されている.この浴面下に下向き $45^{\circ}$ の 逆 $\mathrm{Y}$ 型 2 孔ランス (それぞれ $25.4 \mathrm{~mm} \phi$ ) を所定深さ まで浸漬する.このランスを介して， $3 \mathrm{Nm}^{3} / \min$ の $\mathrm{N}_{2}$ ガス流量 $\left(G_{\mathrm{gas}}=3.75 \mathrm{~kg} / \mathrm{min}\right)$ にのせて $\mathrm{Mg}$ 粒を吹 き込む. $\mathrm{Mg}$ 粒の吹き込み速度は $4.17 \mathrm{~kg} / \mathrm{min}(M=$ $2.86 \mathrm{~mol} / \mathrm{sec})$ である.なお溶銑浴面は不活性䨌囲気に 保持されており, 脱硫生成物, MgS の酸化は起こり得 ないものとする．溶銑中の $\mathrm{S}$ の拡散係数は, GRACEら ${ }^{19}$ の報告值から $1.0 \times 10^{-5} \mathrm{~cm}^{2} / \mathrm{sec}$ とした。

操作変数として需国父压力， $P_{a}$ ，ガス浸漬率， $\beta$ およ び $\mathrm{Mg}$ 粒のサイズ， $n_{0}$ を選び，これらを以下のごとく 変化させて脱硫におよぼす効果を評侕した。

$$
\begin{aligned}
P_{a} & =0.1,1(\mathrm{~atm}) \\
\beta & =0.4,0.6,0.8,1.0 \\
n_{0} & =3.0 \times 10^{-4}(2 \mathrm{~mm} \phi), 2.40 \times 10^{-3}(4 \mathrm{~mm} \phi)(\mathrm{mol})
\end{aligned}
$$

計算結果を Fig. 6 〜 8 に示した。 これらは $\beta$ をパラ メータとして， $\mathrm{S}$ 浱度および $\mathrm{Mg}$ 利用効率 $\varphi$ および $\Omega$ の処理時間に伴う変化を示している.

Fig. 9 には参考までに，不活性雲囲気下で実施したホ ット・モデルの実験条件として, $P_{a}=1 \mathrm{~atm}, \quad M=2.92$ $\times 10^{-4} \mathrm{~mol} / \mathrm{sec}, \quad n_{0}=4.3 \times 10^{-5} \mathrm{~mol}, \quad W=2.17 \times 10^{3}$ $\mathrm{cm}^{3}, D_{i}=2 \times 10^{-5} \mathrm{~cm}^{2} / \mathrm{sec}^{16)}$ などを用いて，上と同様 にして求めた理論曲線と実測值の比較を示す. Fig. 9 に は現場実験データも示したが，これらについては後述す ๖. 
5. 考

察

\section{$5 \cdot 1$ ホット・モデの脱硫速度}

予備実験として行なつた $15 \mathrm{~kg}$ のホット・モデルでは Mg の切り出し速度を一定にすることができなかつたこ 上，黑鉛リングによりスプラッシュのるつぼ外への飛政 を極力防止はしたものの，实駼終了後には約 $3 \mathrm{~kg}$ の地 鉄が浴バルクから飛び出していたこと，あるいはまた， $\mathrm{Mg}$ 供給時のランス内線速度が小さいので， $\mathrm{Mg}$ はラン ス内で気化していた可能性が十分にあること，などのた めに今回設定した反応モデルが厰密には成り立たない。 つまり脱硫を開始してしばらくは，浴面より上部のるつ

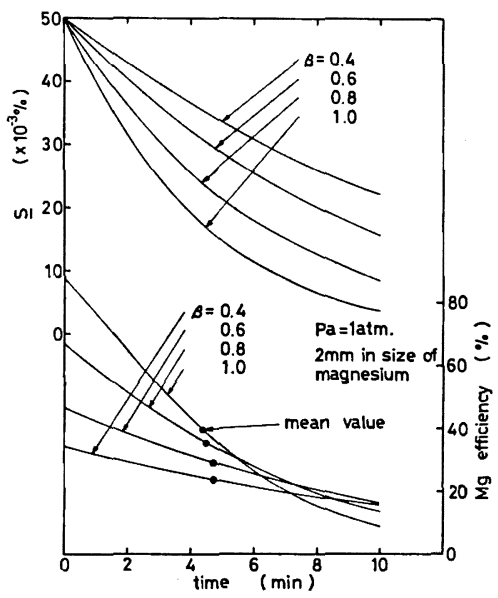

Fig. 6. Computed results of desulfurization rates by magnesium injection of 4.2 $\mathrm{kg} / \mathrm{min}$ into hot metal.

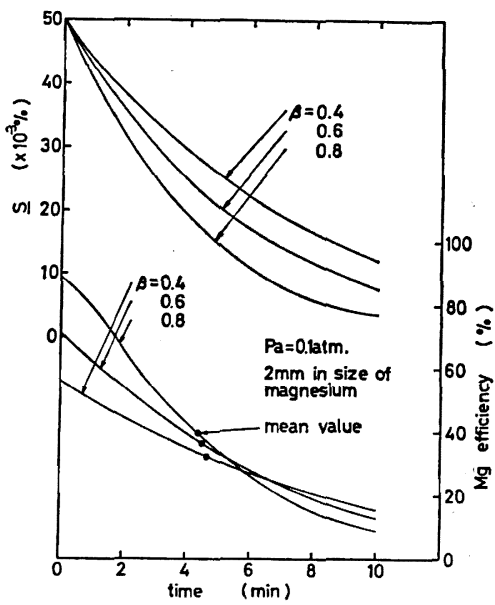

Fig. 7. Computed results of desulfurization rates by magnesium injection of 4.2 $\mathrm{kg} / \mathrm{min}$ into hot metal of $47 \mathrm{t}$.
ぼ内壁にスプラッシュが付着していないため，地鉄は直 惔るつぼ外まで飛散する。このため初期の $\mathrm{Mg}$ 添加量は 少量に抑えた。一方脱硫後期は付着地金のスクリーニン グにより，スプラッシュがるつぼの外へ飛び出す频度が 少なくなるので，初期に比較して $\mathrm{Mg}$ 添加速度を增すこ とができた．Fig. 8 の不一致には，そのような傾向が認 められる。

\section{$5 \cdot 2$ 工業規模での脱硫速度}

(1) 理論式からの推測

Fig. 6〜8 から以下の事柄が明らかである.

（1）ガス浸漬率， $\beta$ は脱硫速度に著しい影響を打よぼ す. 理想的には取鍋の底から $\mathrm{Mg}$ 気泡が浮上する条件で 脱硫すべきである．このことは，鉄浴面から浸渍するラ ンスの場合，ランス先端が鍋底に到達することを意味し ない.すなわち，ガス・ジェットの先端が鍋底に到達す る位置にランスを浸漬すればよい。

IGWE ら 19) は広範囲のモデル実験によりジェット長さ の水平成分および鉛直成分を求める経験式を，ガスのレ

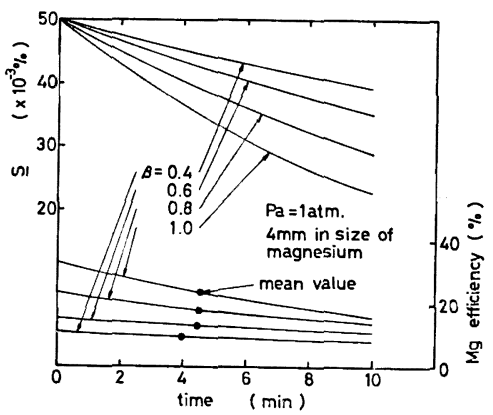

Fig. 8. Computed results of desulfurization rates by magnesium injection of 4.2 $\mathrm{kg} / \mathrm{min}$ into hot metal of $47 \mathrm{t}$.

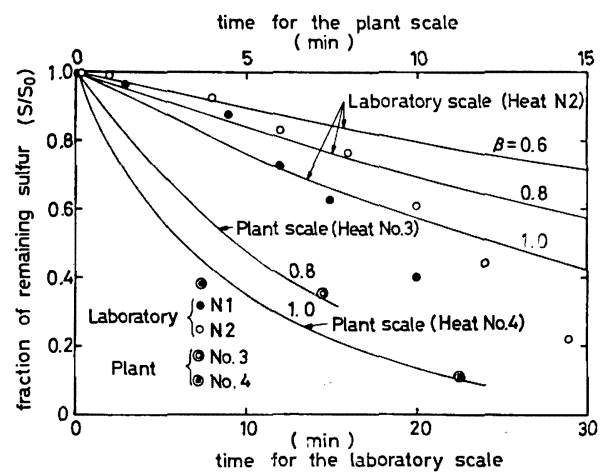

Fig. 9. Comparison of computed desulfurization rates and observed ones under inert atmosphere. 
イノルズ数が $10^{4}$ より大なる場合に，以下のごとく与え た.

$$
\begin{aligned}
& L_{V}=1.20 P_{1} d_{0} \cos \theta+0.78 \\
& L_{H}=2.04 P_{1} d_{0} \sin \theta+5.6
\end{aligned}
$$

ここに， $L_{V} ， L_{H}$ はそれぞれジェットの垂直距離 (in.) および水平距別 (in.), $P_{1}$ は出口压力 (psi), $d_{0}$ はノズ ル径 (in.) および $\theta$ はノズル中心軸が下向き鉛直軸と な寸角度である. 4.3 で述べた設定条件にランス没涉深 さ $700 \mathrm{~mm}$ を加えて $L_{V}, L_{H}$ を算出すれば， $\beta$ は 0.63 に相当する．これより $700 \mathrm{~mm}$ の暴漬深さではジェッ 卜先端は浴底部に十分届いておらず脱硫反応上好交しく ないそそこでシェット先端を溶銑銅底になで届かせるに 必要なランス浸漬深さを(33)，(34) 式より逆算すれば 浴の全深さが， $2500 \mathrm{~mm}$ の時 $1790 \mathrm{~mm}, 2000 \mathrm{~mm}$ の 封 $1380 \mathrm{~mm}$ および $1500 \mathrm{~mm}$ の時 $970 \mathrm{~mm}$ などと求を る. ところで理想的なランス浸漬深さを選択すると, 他 方では，ランスの溶損閉塞などのトラブルが增すである う.したがつて実際上は経済的観点から最適浸漬深さが 決をるものと思われる。

(2) $\mathrm{Mg}$ 利用効率は溶銑 $\mathrm{S}$ 濃度と単調増加の関係にあ り，脱硫初期には高いが，溶銑中の濃度の $\mathrm{S}$ 低下に伴つ て漸次隇少する。これより現場操業においても脱硫の前 期，中期，および後期と $\mathrm{Mg}$ 吹き込み量を漸次下げてい くのが経済的に有利であるといえる.

(3) 減圧の効果をみるため, 仮に零囲気圧を $0.1 \mathrm{~atm}$ とすれば，気泡は膨張し反応界面積が増大寸るので，脱 硫速度も增加する。

(4) $\mathrm{Mg}$ の粒径が $2 \mathrm{~mm}$ の場合の Fig. 6 と $4 \mathrm{~mm} の$ 場合の Fig. 8 を比較すれば, 前者の方が脱硫速度が著 しく速い。これは小粒子の方が脱硫反応の界面栍が増大 し，かつ気泡の浴内滞留時間も，延唇するからである. しかしあ⿱り小さなサイズとすれば， $\mathrm{Mg}$ 粒は $\mathrm{N}_{2}$ ガス にくる亡れたままで浮上して浴面上へ逸出するといつ た反応効率上好ましくない事態が予想される. 4.3 の設 定条件の中で，ガス吹き込み流量と $\mathrm{Mg}$ 粒径を変えて （8）式より粒の離脱距離を求めれば，Fig. 10 ようであ る. 先に設定したガス流量 $3 \mathrm{Nm}^{3} / \min$ は線速度にして 約 $200 \mathrm{~m} / \mathrm{sec}$ であるので，径が $1 \mathrm{~mm}$ の $\mathrm{Mg}$ 粒なら約 $10 \mathrm{~mm}$ 離脱するので問題ない. しかし径が $0.1 \mathrm{~mm}$ と なると先にみたように界面エネルギー変化の効果も大と なりガス・ジェットからの離脱がむつかしくなる．結局 最適粒径は 0.1 から $1 \mathrm{~mm}$ の間にあると考学られるが それは $\mathrm{Mg}$ 脱硫剂の価格, 保管時の安全性などを勘案し て決められるであろう.

（2）現場実験との比較
以下本モデルの妥当性を示す工業規模の実駼結果を述 べる. 不活性需围父下での $\mathrm{Mg}$ 脱琉が必須であるので, $60 \mathrm{t}$ 淮銧鋿に耐火物で被稪した蓋を設け，Ar ガスをパ ージして 浴面上の雲团気を不活性にした。平均径が 2 $\mathrm{mm}$ の金属 $\mathrm{Mg}$ 粒（純度 $95 \%$ 以上）はロータリー・フ イーダを使用し，先の理論計算の設定と同じ逆Y型 2 孔 ランス（黑鉛製）を使用して溶銑中に吹き込えだ. 4 七 一トの実駼絬果を Table 4 に示す. 脱硫処理により溶 銑温度は約 $20^{\circ} \mathrm{C}$ 低下寸る. 溶銑中の $\mathrm{S}$ の昖散係数は $1400^{\circ} \mathrm{C}$ では $1.5 \times 10^{-5} \mathrm{~cm}^{2} / \mathrm{sec}$ とした. Table 4 には (33)，(34) 式からガス・ジェットの浸透深さを補正した ランス沒漬率， $\beta$ および脱硫呠度の理論值が実測值と一 致するように決めた $\beta$ 值を比較して示した. Fig. 9 に は，2 例について理諭式と実測值を対比して示した。こ れらより，実験結果は本モデルによりよく説明されてお り，本モデルの妥当性が結論づけられる.

\section{6. 結}

\section{言}

溶銑の $\mathrm{Mg}$ 吹き込みによる脱硫法について，ホット・ モデルとコールド・モデルによる予供実駼を行なつた. これらの結果をもとに，工業的規模での脱硫反応速度を 与元る理諭式を導出し, 操作变数の影響を定量的に明ら かにした. $60 \mathrm{t}$ 溶銑を对象に実施した現場実駼結果は， 本モデルにより比較的よく説明された。

得られた結諭を要約すれば以下のとおりである.

(1) $\mathrm{Mg}$ 粒吹き込み時の浴面を $\mathrm{Ar}$ などの不活性力゙ スに置換することは脱硫率向上に著しく効果がある。大 父下の場合, いつたん生成した $\mathrm{MgS}$ の約 $60 \%$ が酸化

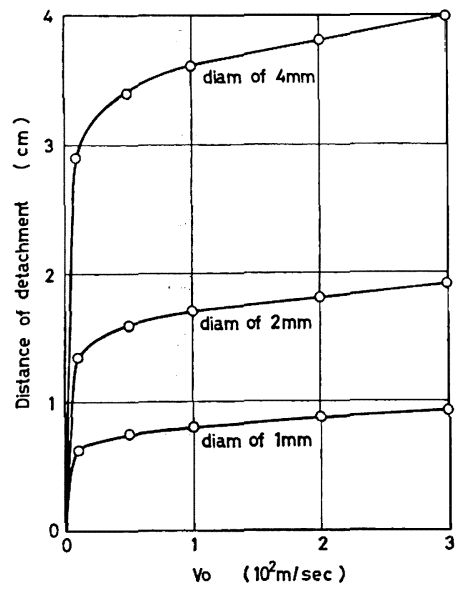

Fig. 10. Predicted distance of detachment of magnesium particles from jet front as a function of linear gas velocity. 
Table 4. Plant-scale results of $\mathrm{Mg}$ desulfurization under inert atmoshere.

\begin{tabular}{c|c|c|c|c|c|c|c|c|c}
\hline $\begin{array}{l}\text { Heat } \\
\text { No. }\end{array}$ & $\begin{array}{c}\text { Heat size } \\
(t)\end{array}$ & $\begin{array}{c}\text { Temp. } \\
\left({ }^{\circ} \mathrm{C}\right)\end{array}$ & $\begin{array}{c}\text { Amount } \\
\text { of } \mathrm{Mg} \\
(\mathrm{kg} / t)\end{array}$ & $\begin{array}{c}\text { Flow rate } \\
\text { of } \mathrm{N}_{2} \\
\left(\mathrm{Nm}^{3} / \mathrm{min}\right)\end{array}$ & $\begin{array}{c}\text { Time of } \\
\text { treatment } \\
(\mathrm{min})\end{array}$ & $\begin{array}{c}\text { Initial } \\
\mathrm{S} \\
(\%)\end{array}$ & $\begin{array}{c}\text { Final } \\
\mathrm{S} \\
(\%)\end{array}$ & $\begin{array}{c}\beta \\
\text { actual }\end{array}$ & $\begin{array}{c}\beta \\
\text { predicted }\end{array}$ \\
\hline 1 & 60.5 & 1350 & 0.35 & 2.5 & 4.7 & 0.022 & 0.011 & 0.8 & 0.70 \\
\hline 2 & 60.4 & 1350 & 0.33 & 2.6 & 5.3 & 0.023 & 0.010 & 0.8 & 0.78 \\
\hline 3 & 62.1 & 1425 & 0.40 & 2.4 & 7.2 & 0.014 & 0.005 & 0.8 & 0.80 \\
\hline 4 & 51.5 & 1310 & 0.68 & 2.0 & 11.3 & 0.048 & 0.007 & 1.0 & 1.0 \\
\hline
\end{tabular}

され溶銑中に復硫した。

（2）吹き込みガスに $\mathrm{N}_{2}$ ガスを使用すると $\mathrm{Mg}_{3} \mathrm{~N}_{2}$ が生成し，ランス詰まりの一因となるようであるが，そ の量は少なく, 脱硫反応の律速段階を考える上では無視 できる。

（3）固気流中の固体粒子がガスジェットからバルク 液中へ離脱する距離を与える推定式を導き，コールド · モデルによりその妥当性を示した.たとえば $3 \mathrm{Nm}^{3} / \mathrm{min}$ の $\mathrm{N}_{2}$ ガスとともに吹き込んだ径が $2 \mathrm{~mm}$ の $\mathrm{Mg}$ 粒は ジェット先端から最大 $18 \mathrm{~mm}$ 溶銑中へ飛び出す.

（4）熱計算によれ泣，（3）の $\mathrm{Mg}$ 粒は，その後 0.01 $\sec$ 後には Mg 蒸父から成る父泡となり, 浴中を浮上す る.

（5）脱硫反応の律速段階が父泡界面へのS O拡散過 程にあるものとして, 脱硫反応速度の 理論式を導出し た. ガス浸漬㵏， $\beta$ は脱硫速度に著しい影響を与え，理 想的には取鍋の底から Mg 父泡が浮上する条件で脱硫す ベきである.雾囲気压力を減在にすれば父泡は膨涱し反 応界面糟が増大寸るので, 脱硫速度も増す. $\mathrm{Mg}$ 粒径を 小さくすれば，界面積の増大と同時に Mg 気泡の浴内滞 留時間が延長するので, 脱硫速度は著しく増す. しかし 小さ過ぎれば $\mathrm{N}_{2}$ ガスからの蓶脱が不可能となり, 反応 効率は低下することになろう。これらの結果, 最邀サイ ズは 0.1 から $1 \mathrm{~mm}$ の間にあるものと思われる.

\section{交献}

1 ) 水野富行, 多賀雅之, 大井淳一, 佐藤光信, 長尾 典昭：鉄之鋼，62 (1976), S 82

2 ) 草川隆次，アルトウロ・ゴンザレス，レ・テェン テイン: 鉄と鋼, 62 (1976), S 83

3 ) $M . C$. Ashton, R. K. Buhr, J. G. Magney, and $K . G$. DAvis: Ironmaking and Steelmaking
(1975) No. 2, p. 111

4) I. G. Polovchenko, et al.: Izvest. VUZov, Cher. Met., April 1964, p. 31

5 ) E. F. KurZinsKi: Iron and Steel Eng., (1976), April, p. 59

6 ) D. P. Maltly: Special Conference on Desulphurization of Hot Metal, Tronto, Canada, (1975) April

7 ) 梨和甫, 山口 進, 鶠野雅志, 岩見紀元: 住友 金属， 27 (1975)，p. 63

8 ) 杉田宏, 足立隆彦, 山口進, 永幡勉, 辻田 進: 鉄と鋼, 62 (1976), S 530

9 ) $N$. A. Voronova, $S . T$. Pliskanovskit, $A . F$. Shevchenko, $M$. L. Lavrentév, and $I Y a$. Emelyanov: Steel in USSR (1974), April, p. 261

10) J. Chipman: Basic Open Hearth Steelmaking, ed. by G. Derge, (1964), p. 678 [AIME]

11) T. $A$. Engh, $H$. Sandberg, $A$. Hultkvist, and L. G. Norberg: Scand. J Met., 1 (1972), p. 103

12) R. B. Bird, W. E. Stewart, and E. N. Lightfoot: Transport Phenomena, (1960), p. 192 [John Wiley \& Sons.]

13）日本化学会編：化学便覽，基礎編，(1975), p. 985 [丸善]

14) $H$. S. Carslaw and J. C. Jaeger: Conduction of Heat in Solids, 2nd ed., (1959), p. 102 [Oxford Lniversity Press]

15）化学工学協会編：化学工学便覧，(1975), p. 228, p. 35 [丸善]

16) J. Szekely and N.T. Themelis: Rate Phenomena in Process Metallurgy, (1970), p. 690 [John Wiley \& Sons]

17) M. H. T. Baird and J. F. Davidson: Chem. Eng. Sci. 17 (1962), p. 87

18) R. E. Grace and G. Derge: Trans. Met. Soc. AIME, 212 (1958), p. 331

19) B. U. N. Igwe, S. Ramachandron, and $J . C$. Fulton: Met. Trans., 4 (1973), p. 1887

20) N. B. VARGAFTIK：便臨，気体と液体の熱物理的 性質 (1972)，p.86 [日ソ通信社] 